\title{
Species-specific PCR primers for identification of the sibling species Chironomus plumosus (Linnaeus, 1758) and Chironomus balatonicus (Devai, Wuelker et Scholl, 1983) (Chironomidae, Diptera)
}

\author{
Larissa I. Gunderina'
}

\begin{abstract}
Gunderina LI. 2012. Species-specific PCR primers for identification of the sibling species Chironomus plumosus (Linnaeus, 1758) and Chironomus balatonicus (Devai, Wuelker et Scholl, 1983) (Chironomidae, Diptera). Fauna norvegica 31: 151-157.
\end{abstract}

\begin{abstract}
Applicability of the polymerase chain reaction (PCR) with species-specific primers to obtaining molecular markers for identification of the sibling species of Chironomus plumosus group - $C$. plumosus and $C$. balatonicus - has been estimated. The nucleotide sequences of internal transcribed spacer (ITS) from the locus encoding ribosomal RNA (rRNA) were used as the source for designing the species-specific primers. The primers allowing for identification of $C$. plumosus and C. balatonicus were constructed. One primer pair (plu107F/plu363R) gives the PCR product MAR2, specific of $C$. plumosus, and the other (bal86F/plu363R), the PCR product MAR6, specific of $C$. balatonicus. The testing involving 18 species of the genus Chironomus confirmed the specificity of the primers. The results suggest that the PCR with species-specific primers is promising for construction of molecular markers for identification not only of these two, but also of other Chironomus species.
\end{abstract}

doi: 10.5324/fn.v31i0.1381. Received: 2011-10-15. Accepted: 2012-06-27.

Published on paper and online: 2012-10-17.

Keywords: Chironomus plumosus, C. balatonicus, species identification, internal transcribed spacer (ITS), species-specific PCR primers

1. Institute of Cytology and Genetics SB RAS, 630090 Novosibirsk, Russian Federation

E-mail: gund@bionet.nsc.ru

\section{INTRODUCTION}

Chironomus plumosus and C. balatonicus are sibling species from the $C$. plumosus group. This group comprises at least nine species, namely, C. plumosus (Linnaeus, 1758), C. agilis Shobanov \& Djomin, 1988, C. balatonicus Devai, Wuelker \& Scholl, 1983, C. bonus Shilova \& Dzvarsheishvili, 1974, C. borokensis Kerkis, Filippova, Shobanov, Gunderina \& Kiknadze, 1988, C. entis Shobanov, 1989, C. muratensis Ryser, Scholl \& Wuelker, 1983, C. nudiventris Ryser, Scholl \& Wuelker, 1983, C. usenicus Loginova \& Beljanina, 1993. Chironomus plumosus and C. balatonicus frequently live sympatrically; however, no hybrids between these species have been found in wildlife. Under laboratory conditions, C. plumosus females successfully mate with $C$. balatonicus males. The backcrossing is successful for the hybrid males and C. plumosus females. Up to $50 \%$ of the embryos survive in both crosses, direct and backcrossing (Michailova \& Fischer 1985). Chironomus plumosus and C. balatonicus are hardly distinguishable based on their morphology; however, certain characters allowing for discrimination of their larvae have been described (Shobanov 1989). These species can be reliably identified only according to the banding pattern of the salivary gland polytene chromosomes (Devai et al. 1983; Kiknadze et al. 1991). Chironomus plumosus is widespread in the Holarctic aquatic bodies, while $C$. balatonicus has been found in Eurasia in populations of Western and Eastern Europe, Siberia, Altai, and Kazakhstan (Devai et al. 1983; Golygina et al. 1996; Gunderina et al. 2008). As for Nearctic, cytogenetic analysis of the larvae collected in over 50 aquatic bodies of North America has demonstrated that, in addition to C. plumosus, the samples contained its sibling species $C$. entis, whereas $C$. balatonicus has not been found in any of these populations (Kiknadze et al. 
2000). Moller Pillot (2009) assumed that the difference between C. plumosus and C. balatonicus in their geographic distribution along with ecological factors could result from an insufficiently accurate identification of these species and distinguishing between them. This demonstrates the demand for a reliable identification and differentiation of these sibling species.

Two approaches provide for the most precise methods for identifying chironomid species - karyotype analysis and DNA sequencing. However, a cytogenetic identification of chironomid species has a certain limitation, since this method is applicable only to the larvae of the second half of the fourth instar, when their salivary gland polytene chromosomes reach the maximal degree of polyteny. The chromosomes of the younger larvae are insufficiently polytenized and, thus, fail to display a distinct banding pattern allowing for detection of interspecific differences. In pupae, both salivary glands and the chromosomes are destroyed. DNA sequencing has no principal limitations for identification of chironomid species. However, note that highly qualified experts are necessary to reliably identify chironomid species using these two approaches.

Currently, the polymerase chain reaction (PCR) with species-specific primers is ever widely used for species identification. This reaction gives the amplification products only with the target species, for which the corresponding primers have been designed. This method is simple in use and data interpretation. The PCR with species-specific primers has demonstrated its efficiency when identifying species of manifold taxonomic groups (Stewart et al. 2010; Benucci et al. 2011; Harrison et al. 2011).

The best studied in the chironomid nuclear genome is the ribosomal RNA locus and especially the internal transcribed spacer (ITS) region carrying 5.8S rRNA gene and the adjacent spacers, ITS1 and ITS2. By June of 2011, the GenBank database contained the sequences of this region belonging to 24 Chironomus species, including C. plumosus and C. balatonicus. The ITS1 nucleotide sequences of chironomids are highly polymorphic, while 5.8S rDNA are highly conserved. Extended species-specific sequences with their length sufficient for constructing primers have been found in the ITS1 region (Gunderina \& Katokhin 2011). Correspondingly, ITS1 and 5.8S rDNA nucleotide sequences were used to design the speciesspecific primers for $C$. plumosus and $C$. balatonicus.

The primers used for designing species-specific molecular markers to the ITS region intended for identification of chironomids should meet the following requirements: (1) the forward primers should be localized to the regions displaying the highest conservation within the species as well as maximal distinctions between species (reverse primers may not match this condition); (2) the primers should give species-specific amplicons with a length of 200-300 nucleotides; (3) the primers should give the PCR products for only target species; (4) the primer length should be about 20 nucleotides; and (5) the conditions for the PCR with species-specific primers should not differ from the conditions used for synthesizing a full-sized product.

The goal of this work was to design species-specific molecular markers from the rDNA ITS locus providing for identification of $C$. plumosus and $C$. balatonicus with the help of a PCR with species-specific primers.

\section{MATERIALS AND METHODS}

The Chironomus species used in the work are listed in Table 1 with indication of the sampling sites and dates as well as the number of studied larvae. Larvae were fixed in $96 \%$ ethanol and preserved at $-20^{\circ} \mathrm{C}$. The species were identified cytogenetically according to the banding pattern of polytene chromosomes (Kiknadze et al. 1991).

To search for the regions appropriate for designing $C$. plumosus and C. balatonicus species-specific primers, the ITS1 sequences of these and 16 other Chironomus species, available in GenBank and deposited by both the authors (accession numbers GU053584-GU053605 and HQ656600-HQ656601) and other researchers (accession numbers: AJ296806-AJ296822, AJ296767-AJ296774, and AJ296779-AJ296792) were aligned using the software ClustalW (Larkin et al. 2007).

The species-specific PCR primers were designed with the help of the Primer3 program (Rozen and Skaletsky, 2000) using the ITS1 and 5.8S rDNA nucleotide sequences of $C$. plumosus (accession number GU053597) and C. balatonicus (accession number GU053586). The ITS1 region between positions 116 and 147 was selected for the forward primers specific of $C$. plumosus and $C$. balatonicus and the 5.8S rDNA region between positions 357 and 403, for the reverse primers. The positions of the primers are denoted with open boxes (Figure 1). The nucleotide sequences of the primers, their designations, and lengths of the species-specific PCR products are listed in Table 2.

To verify species specificity of the designed primers, DNAs of both the two target species (C. plumosus and $C$. balatonicus) and other Chironomus species listed in Table 1 were used in PCR. No amplification products were obtained in the PCR with species-specific primers and DNAs of the Chironomus species other than the target ones. A positive control $(\mathrm{C}+)$ was used to guarantee that a negative amplification result was determined by the absence of the sequence corresponding to the primer binding site rather than an unsuccessful PCR determined, for example, by a poor DNA quality or any other reasons. PCR with the primer pair 5'-GTAACAAGGTTTCCGTAGG-3' (chir5F) and 5'-CGACACTCAACCATATGTACC-3' (chir5R), giving a full-sized ITS1-5.8S rDNA fragment with a length of $\sim 480 \mathrm{bp}$ (Gunderina \& Katokhin 2011), was used as a positive control.

Identification sensitivity was estimated by the PCR with mixtures of DNAs of Chironomus species. The first mixture $(\mathrm{Mix}+\mathrm{T})$ comprised $1 \mu \mathrm{l}$ of genomic DNA of each of the 18 chironomid species, including the target species, - C. plumosus, C. balatonicus, $C$. agilis, C. borokensis, $C$ entis, $C$. muratensis, C. nudiventris, C. dorsalis Meigen, 1818, C. luridus Strenzke, 
Table I. The list of species of the genus Chironomus Meigen, 1803, sample localities, dates of collection, locality codes and number of larvae analyzed

\begin{tabular}{|c|c|c|c|}
\hline Species & Locality, dates of collection & Code & $\begin{array}{l}\text { No. of } \\
\text { larvae } \\
\text { studied }\end{array}$ \\
\hline Chironomus plumosus & Russia, Tomsk region, Timiryazevo, pond, 08.IV.2005, O. Vaulin & RU-TOM-TI & 15 \\
\hline Chironomus plumosus & $\begin{array}{l}\text { Russia, Kemerovo region, Anzhero-Sudzhensk, pond, 21.V.2004, V. } \\
\text { Golygina \& A. Istomina }\end{array}$ & RU-KEM-AN & 15 \\
\hline Chironomus plumosus & USA, Minnesota, Christina lake, 12.VII.2004, M. Butler & US-MN-CH & 15 \\
\hline Chironomus balatonicus & $\begin{array}{l}\text { Bulgaria, Burgas, Burgas lake, 23.II.2002, B. Krastanov \& P. } \\
\text { Michailova }\end{array}$ & BG-BUR-BL & 15 \\
\hline Chironomus balatonicus & $\begin{array}{l}\text { Russia, Novosibirsk region, Kaltyrak, Kaltyrak river, 16.V.2002, V. } \\
\text { Golygina \& A. Istomina }\end{array}$ & RU-NSK-KL & 15 \\
\hline Chironomus agilis & $\begin{array}{l}\text { Russia, Novosibirsk region, Yurty, Tarsma river, 14.V.2002, V. } \\
\text { Golygina \& A. Istomina }\end{array}$ & RU-NSK-TR & 5 \\
\hline Chironomus borokensis & $\begin{array}{l}\text { Russia, Novosibirsk region, Eltyshevo, Kayly river, 16.V.2002, V. } \\
\text { Golygina \& A. Istomina }\end{array}$ & RU-NSK-KL & 5 \\
\hline Chironomus entis & Russia, Moscow region, reservoir, 04.III.2006, E. Izvekova & RU-MOS-UW & 5 \\
\hline Chironomus muratensis & $\begin{array}{l}\text { Russia, Novosibirsk region, Sokur, Ora river, 17.V.2002, V. } \\
\text { Golygina \& A. Istomina }\end{array}$ & RU-NSK-OR & 5 \\
\hline Chironomus nudiventris & Russia, Novosibirsk, Ob reservoir, 01.V.2002, L. Gunderina & RU-NSK-OS & 5 \\
\hline Chironomus dorsalis & Russia, Novosibirsk, "Crystal”, tank, 22.VIII.2008, L. Gunderina & RU-NSK-CR & 5 \\
\hline Chironomus dorsalis & Russia, Novosibirsk “Geneticist”, tank, 06.VIII.2008, L. Gunderina & RU-NSK-GN & 5 \\
\hline Chironomus luridus & Russia, Novosibirsk, "Crystal”, tank, 21.IX.2005, L. Gunderina & RU-NSK-CR & 5 \\
\hline Chironomus pseudothummi & Russia, Novosibirsk, "Crystal”, tank, 21.IX.2005, L. Gunderina & RU-NSK-CR & 5 \\
\hline Chironomus pseudothummi & Russia, Novosibirsk, “Geneticist”, tank, 26.VII.2010, L. Gunderina. & RU-NSK-GN & 5 \\
\hline Chironomus piger & Kazakhstan, Almaty, pond, 11.VII.2001, O. Lopatin & KZ-AA-ZI & 5 \\
\hline Chironomus riparius & Russia, Novosibirsk, “Geneticist”, tank, 23.VIII.2008, L. Gunderina & RU-NSK-GN & 5 \\
\hline Chironomus riparius & $\begin{array}{l}\text { Russia, Kemerovo region, Prokopyevsk, Bolshoy Kerlegesh lake, } \\
\text { 03.VII.2005, L. Gunderina }\end{array}$ & RU-NSK-GN & 5 \\
\hline Chironomus annularius & $\begin{array}{l}\text { Russia, Novosibirsk region, Karasuk, Krotovo lake, 01.V.2008, V. } \\
\text { Golygina }\end{array}$ & RU-NSK-KT & 5 \\
\hline Chironomus staegeri & USA, Minnesota, Rainy lake, 09.VI.2004, M. Butler & US-MN-RA & 5 \\
\hline Camptochironomus tentans & $\begin{array}{l}\text { Russia, Novosibirsk, Ob river, 14.V.2004., V. Golygina \& A. } \\
\text { Istomina }\end{array}$ & RU-NSK-RP & 5 \\
\hline Chironomus dilutus & USA, Minnesota, Anderson lake, 2/8.X.2001, M. Butler & US-MN-AND & 5 \\
\hline $\begin{array}{l}\text { Camptochironomus pal- } \\
\text { lidivittatus }\end{array}$ & $\begin{array}{l}\text { Russia, Novosibirsk region, Karasuk, Chebachje lake, 10.VII.2001, } \\
\text { A. Istomina }\end{array}$ & RU-NSK-CH & 5 \\
\hline Chironomus setivalva & $\begin{array}{l}\text { Russia, Altai Krai, Tyumentsevo, Gorkoje lake, 13.V.2003, V. } \\
\text { Golygina \& A. Istomina }\end{array}$ & RU-ALT-GT & 5 \\
\hline
\end{tabular}


Table 2. Primers designed to amplify species-specific markers of $C$. plumosus and C. balatonicus.

\begin{tabular}{llllll}
\hline Species & Marker & Primer & Primer name & Primer sequence (5' - 3') & $\begin{array}{l}\text { Marker } \\
\text { length (bp) }\end{array}$ \\
\hline $\begin{array}{l}\text { C. plumosus } \\
\text { (GU053597) }\end{array}$ & MAR2 & forward & plu107F & TGTGCTTGTGTGTCAAACG & 257 \\
C. balatonicus & & reverse & plu363R & GCGTTCAACATGTCAATGAT & 249 \\
(GU053586) & MAR6 & forward & bal86F & TGAGTGTTAAACGCACACAT & 2 \\
\hline
\end{tabular}

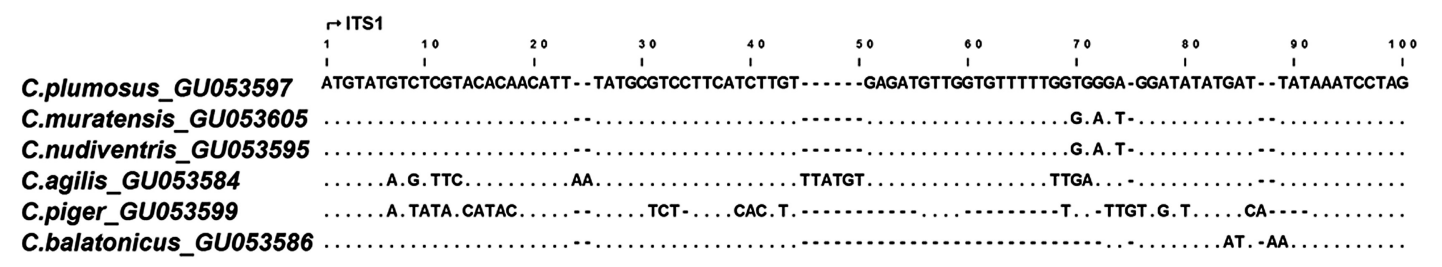
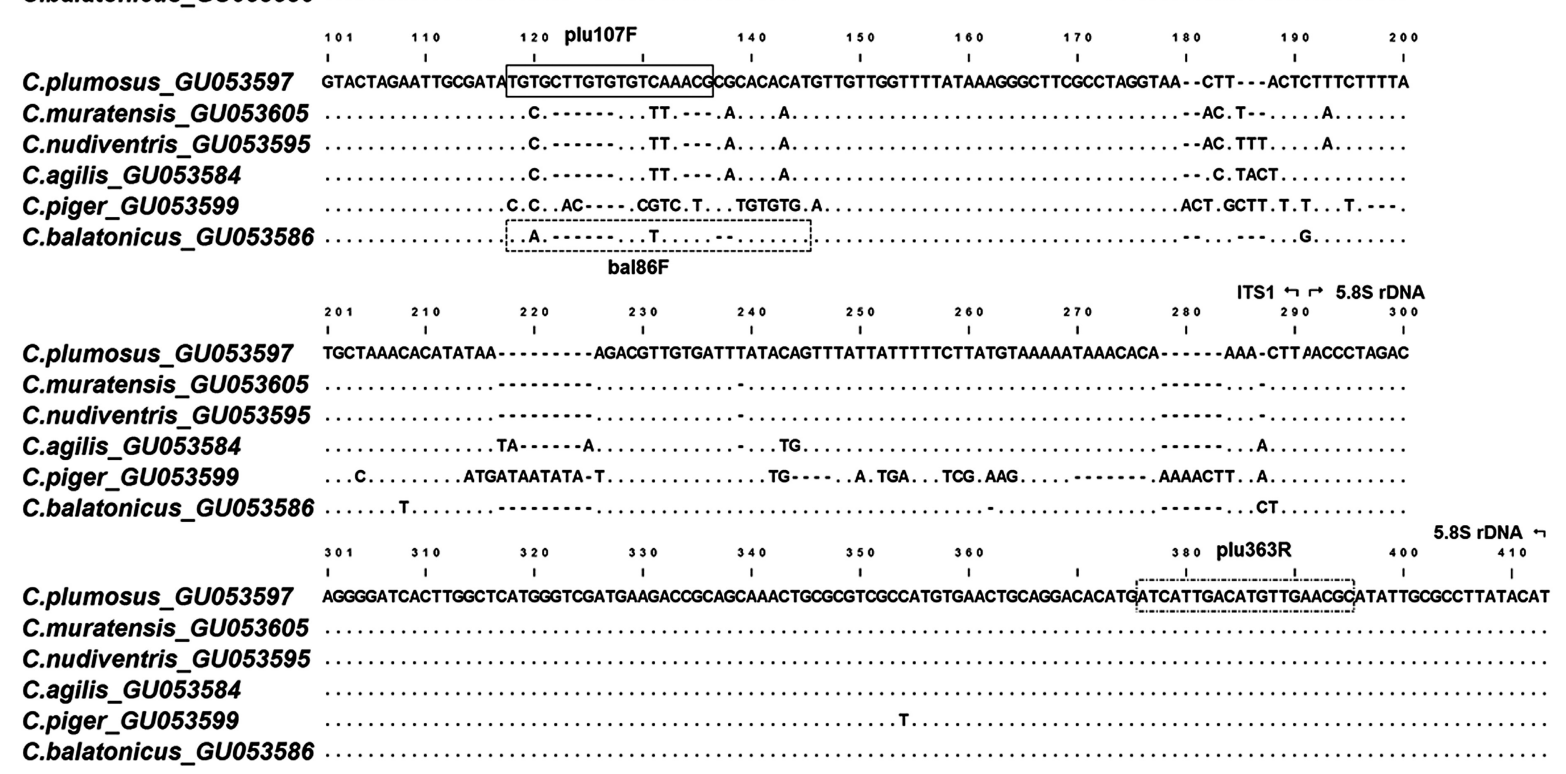

Figure I. Multiple alignments of ITS1 and 5.8S rDNA sequences of six Chironomus species. The positions of the primers designed are indicated with open boxes: plu107F (bold borders); bal86F (dot borders); plu363R (dot-dash borders).

1959, C. pseudothummi Strenzke, 1959, C. piger Strenzke, 1959, C. riparius Meigen, 1804, C. annularius Meigen, 1818, C. staegeri Lundbeck, 1898, C. tentans Fabricius, 1805, C. dilutus Shobanov, Kiknadze \& Butler, 1999, C. pallidivittatus Malloch, 1915, C. setivalva Shilova, 1957. The second mixture (Mix-T) contained $1 \mu \mathrm{l}$ of each of 12 species $(C$. agilis, $C$. borokensis $C$ entis, C. muratensis, C. nudiventris, C. luridus, C. annularius, C. staegeri, C.tentans, $C$. dilutus, C. pallidivittatus, C. setivalva) lacked the DNA of the target species. When conducting PCR, 1 $\mu l$ of DNA mixture was added to the reaction mixture.

Genomic DNA was isolated from individual larvae according to Bender et al. (1983) or using a DNeasy Blood and Tissue Kit (QIAGEN) according to the manufacturer's protocol.

The PCR mixture $(25 \mu \mathrm{l})$ contained $65 \mathrm{mM}$ Tris- $\mathrm{HCl}(\mathrm{pH}$ 8.9), $16 \mathrm{mM}\left(\mathrm{NH}_{4}\right)_{2} \mathrm{SO}_{4}, 0.05 \%$ Tween $20,1.5 \mathrm{mM} \mathrm{MgCl}_{2}, 0.2$
mM of each dNTP, 25-50 ng of DNA template, $0.5 \mu \mathrm{M}$ of each primer, and $1 \mathrm{U}$ of Taq polymerase (BIOSAN, Novosibirsk, Russia). The PCR mode comprised the initial denaturation at $94^{\circ} \mathrm{C}$ for $1 \mathrm{~min}$ and 25 cycles of $94^{\circ} \mathrm{C}$ for $30 \mathrm{~s}, 57^{\circ} \mathrm{C}$ for 30 $\mathrm{s}$, and $72^{\circ} \mathrm{C}$ for $45 \mathrm{~s}$. The PCR products were separated by electrophoresis in $1.5 \%$ agarose gel in $1 \times$ TAE buffer, stained with ethidium bromide, and visualized in a transilluminator.

\section{RESULTS}

Figure 2 shows the results of DNA amplification of the $C$. plumosus from natural Siberian (RU-TOM-TI and RU-KEMAN) and North American (US-MN-CH) populations with the primer pair plu107F/plu363R, designed for this species. It is evident that independently of their geographic origin, the 


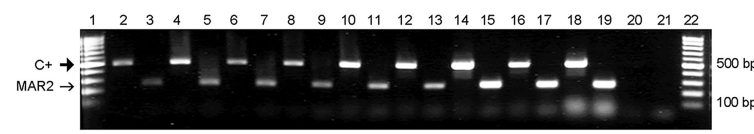

Figure 2. PCR products (MAR2) obtained with the primer pair plu107F/plu363R and DNA of different individuals of $C$. plumosus from three natural populations. 2 - 7 - population RU-TOM-TI, 8 - 13 - population RU-KEM-AN, 14 - 19 population US-MN-CH, 2, 4, 6, 8, 10, 12, 14, 16, 18 - positive control (C+); 3, 5, 7, 9, 11, $13,15,17,19$ - MAR2, 20 - negative control to $\mathrm{C}+; 21$ - negative control to MAR2; 1 and $22-100$ bp marker.

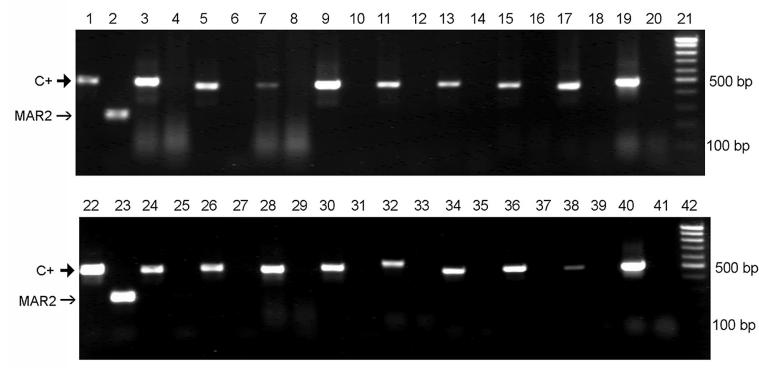

Figure 3. PCR products (MAR2) obtained with DNA of 18 Chironomus species and the primer pair plu107F/plu363R. 1, 3, 5, 7, 9, 11, 13, 15, $17,19,22,24,26,28,30,32,34,36,38,40$ - positive control (C+); $2,4,6,8,10,12,14,16,18,20,23,25,27,29,31,33,35,37,39$, 41 - MAR2. 1, 2, 22, 23 - C. plumosus; 3, 4-C. agilis; 5, 6-C. balatonicus; 7, 8, 24, 25-C. borokensis; $9,10-C$ entis; $11,12-C$. muratensis; $13,14-$ C. nudiventris; 15,16 - C. pseudothummi; 17, 18 - C. luridus; 19, 20 - C. dorsalis; 26, 27 - C. piger; 28, $29-$ - . riparius; $30,31-C$. annularius; $32,33-C$. staegeri; $34,35-C$. tentans; 36, 37 - C. dilutus; 38, 39 - C. pallidivittatus; $40,41-C$. setivalva; 21,42 - 100 bp marker.

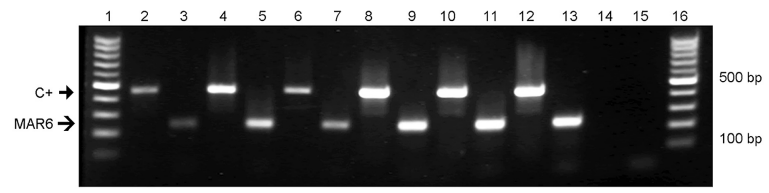

Figure 4. PCR products (MAR6) obtained with the primer pair bal86F/plu363R and DNA of different individuals of C. balatonicus from two natural populations. $2-7$ - population BG-BUR-BL, 8 - 13 - population RU-NSK-KL, 2, 4, 6, 8, 10, 12 - positive control (C+); 3, 5, 7, 9, 11, 13 - MAR6, 14 - negative control to C+; 15 - negative control to MAR6; 1, 16 - 100 bp marker.

samples give one amplicon with a size of $\sim 260 \mathrm{bp}$. It length corresponds to that of the predicted PCR product (Table 2). No amplification products with this primer pair are formed when using the DNAs of other Chironomus species as a template, although the concurrently conducted control reaction with the primer pair chir5F/chir5R $(\mathrm{C}+)$ gives a full-sized ITS1-5.8S fragment with a length of $\sim 480 \mathrm{bp}$ for all the species (Figure 3 ), thereby demonstrating that a negative amplification does not result from an unsuccessful reaction or DNA damage.

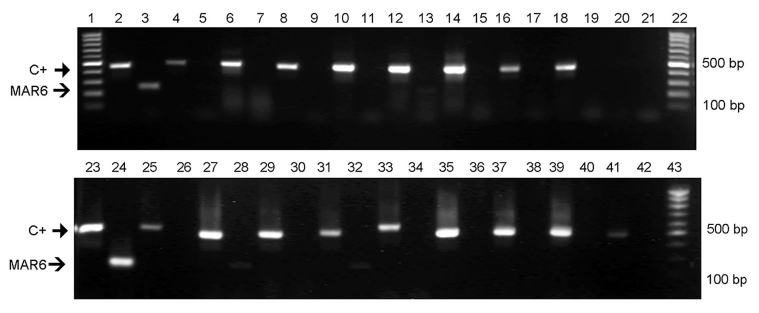

Figure 5. PCR products (MAR6) obtained with DNA of 18 Chironomus species and the primer pair bal86F/plu363R. 2, 4, 6, $8,10,12,14,16,18,23,25,27,29,31,33,35,37,39,41$ - positive control (C+); 3, 5, 7, 9, 11, 13, 15, 17, 19, 24, 26, 28, 30, 32, 34, 36, 38, 40, 42 - MAR6; 20 - negative control to $\mathrm{C}+; 21$ - negative control to MAR6. 2, 3, 23, 24-C. balatonicus; 4, 5-C. plumosus; 6, 7 - C. agilis; 8, 9-C. borokensis; 10, $11-C$ entis; 12, $13-C$. nudiventris; 14, 15 - C. muratensis; 16, 17 - C. riparius; 18, 19 - C. dorsalis; 25, 26 - C. piger; 27, 28 - C. luridus, 29, 30 - C. pseudothummi; 31,32 - C. annularius; 33, 34 - C. staegeri; 35,36 - C. tentans; 37, 38 - C. dilutus; 39, 40 - C. setivalva; 41, 42 - C. pallidivittatus; 1, 22, 43 - 100 bp marker.

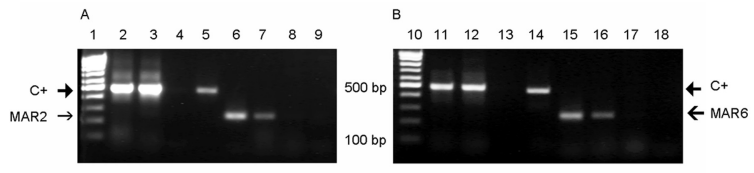

Figure 6. PCR products obtained with mixed DNAs of Chironomus species and primer pairs plu107F/plu363R and bal86F/plu363R. A - primer pair plu107F/plu363R, PCR product MAR2: 2 - 5 - positive control (C+); 6 - 9 - MAR2; 2, 7 - Mix+T DNA; 3, 8 - Mix-T DNA; 5, 6 - C. plumosus; 4, 9 - negative control (C-). 1 - 100 bp marker. B - primer pair bal86F/plu363R, PCR product MAR6: 11 - 14 - positive control (C+); 15 - 18 - MAR6; 11,16 - Mix+T DNA; 12, 17 - Mix-T DNA; 14, 15 - C. balatonicus; 13, 18 - negative control (C-). 1 - 100 bp marker.

Therefore, the primer pair plu107F/plu363R can be regarded as specific for $C$. plumosus and the amplicon with a size of $\sim 260$ bp (MAR2), as a molecular marker for this species.

Figure 4 shows the results of DNA amplification of the $C$. balatonicus from natural Bulgarian (BG-BUR-BL) and Siberian (RU-NSK-KL) populations with the primer pair bal86F/plu363R, designed for this species. All the C. balatonicus individuals give one amplicon with a size matching the length of the predicted product ( $250 \mathrm{bp}$; Table 2 ). No amplification products are formed in the PCR with DNAs of other Chironomus species and this primer pair (Figure 5). The concurrently conducted PCR with the primer pair chir5F/chir5R (C+) is successful for all chironomid species. Consequently, the absence of amplicon in the PCR with the DNAs of non-target species and the primer pair designed for $C$. balatonicus does not result from any technical inaccuracies. Thus, the primer pair bal86F/plu363R can be regarded as specific for $C$. balatonicus and the amplicon with a length of $\sim 250 \mathrm{bp}$ (MAR6), as a molecular marker for 
this species.

To assess the sensitivity of this method, we conducted the PCR with the designed primer pairs and mixtures of the DNAs of chironomid species; one mixture $(\mathrm{Mix}+\mathrm{T})$ contained the DNA of two target species and the other (Mix-T), lacked them (Figure 6). The amplicons MAR2 and MAR6 were obtained by the PCR with the primer pairs specific for C. plumosus and C. balatonicus and the DNA mixture Mix $+\mathrm{T}$. In the case with Mix-T, these amplicons were not synthesized. Consequently, the designed primers make it possible to detect by PCR the presence of C. plumosus and C. balatonicus DNA in the mixture of DNAs of 18 different chironomid species.

\section{DISCUSSION}

Using interspecific differences in the nucleotide sequences of the ITS1-5.8S rDNA region, we succeeded in designing the primers allowing for amplification of the PCR products specific of C. plumosus and C. balatonicus-MAR2 and MAR6, respectively. The nucleotide sequences of the primers plu107F (C. plumosus) and bal86F (C. balatonicus) considerably differ from one another as well as from the nucleotide sequences of this region in other C. plumosus sibling species (Figure 1). The differences between the primers plu107F and bal86F comprise eight indels (insertions/deletions) and two nucleotide substitutions. In the primer binding region, the sequences of the C. plumosus sibling species C. agilis, C. muratensis, and C. nudiventris differ from the plu107F sequence (positions 118-136) by nine indels and three nucleotide substitutions and from the bal86F sequence (positions 118-145) by five indels and three nucleotide substitutions. The species beyond the $C$. plumosus group of sibling species display even more pronounced differences in the region of primer binding sites. In particular, the sequences in question of $C$. plumosus and C. piger differ by four indels and nine nucleotide substitutions (Figure 1). Due to such considerable interspecific differences of Chironomus species in the sequences of their primer binding sites, the PCR with the designed primers and DNAs of 18 Chironomus species gives the marker amplicons MAR2 and MAR6 only in the case of the target species, C. plumosus and C. balatonicus.

As is known, cytogenetic and genetic structures of natural populations of chironomid species considerably vary within their geographic range (Gunderina et al. 1999a, 1999b, 2008, 2009). Therefore, the C. plumosus and C. balatonicus larvae from geographically distant populations were used to test species specificity of the designed primers. Species-specificity of the primer pair plu107F/plu363R was tested using the C. plumosus larvae from the populations RU-TOM-TI, RUKEM-AN and US-MN-CH. The geographic distance between the West Siberian C. plumosus populations RU-TOM-TI and RU-KEM-AN is considerably shorter as compared with that between these populations and the North American population
US-MN-CH. The cytogenetic distances, $\mathrm{D}_{\mathrm{cg}}$ (Nei 1972) between C. plumosus populations from different continents are larger than between the West Siberian populations; however, they yet fall within range characteristic of the cytogenetic differences between the populations of this species (Gunderina et al. 1999a; Kiknadze et al. 2000). The genetic distances, GD (Link et al. 1995) between these populations fit the level of interpopulation genetic differences within a species (Gunderina et al. 2009). Independently of geographic distance between populations and the degree of differentiation of their genetic and cytogenetic structures, all the C. plumosus larvae gave the amplicon MAR2 in the PCR with the primer pair plu107F/plu363R.

The same results were obtained when verifying the species-specificity of the primer pair bal86F/plu363R using the C. balatonicus larvae from Bulgarian (BG-BUR-BL) and West Siberian (RU-NSK-KL) populations. Despite geographic remoteness as well as cytogenetic and genetic differentiation of the populations within this species (Gunderina et al., 1999 b, 2008), all the $C$. balatonicus individuals gave the amplicon MAR6 in the PCR with this primer pair.

Thus, these results suggest that the amplicons MAR2 and MAR6, synthesized in the PCR with the primers designed for C. plumosus and C. balatonicus, can be regarded as speciesspecific molecular markers for these species.

PCR with species-specific primers allows for identification of chironomid species considerably faster than DNA sequencing. However, the time required for $C$. plumosus and $C$. balatonicus identification by this method can be considerably reduced by running PCR on an aliquot of the mixed DNA isolated from candidate chironomid specimens collected from the same water body. This also allows the reagents necessary for PCR and electrophoretic detection of amplification products to be saved. The detection of $C$. plumosus among 20 chironomid individuals requires 40 PCRs to be conducted if specimens are analyzed separately, namely, 20 test reactions (with the species-specific primers giving the amplicon MAR2, species-specific for $C$. plumosus) and 20 control reactions $(\mathrm{C}+$, with the universal primers chir5F/chir5R, characterizing the PCR quality). However, only two PCRs are required to detect the presence of C. plumosus DNA in a mixture of DNA from 20 individual chironomids - one test reaction (with species-specific primers) and one control reaction $(\mathrm{C}+$, with universal primers).

Our results allow us to expect that it is useful to design species-specific PCR primers to obtain species specific molecular markers for identification also of other species of the genus Chironomus.

\section{ACKNOWLEDGMENTS}

The author is grateful to G. Chirikova for translation of the manuscript from Russian into English.

This work was supported by the grant RFBR 10-04-00899 and program of Presidium RAS "Biological Diversity". 


\section{REEERENCES}

Bender W, Spierer P, Hognes DS, Chambon P. 1983. Chromosomal walking and jumping to isolate DNA from the Ace and rosy loci and the bithorax complex in Drosophila melanogaster. Journal of Molecular Biology 168(1): 17-33.

Benucci GMN, Raggi L, Di Massimo G, Baciarelli-Falini L, Bencivenga M, Falcinelli M, Albertini E. 2011. Species-specific primers for the identification of ectomycorrhizal fungus Tuber macrosporum Vittad. Molecular Ecology Resources 11(2): 378381.

Dévai Gy, Wülker W, Scholl A. 1983. Revision der Gattung Chironomus Meigen (Diptera). IX. C.balatonicus sp.n. aus dem Flashsee Balaton (Ungarn). Acta Zoologica Academiae Scientiarum Hungaricae 29(4): 357-374.

Golygina VV, Istomina AG, Rakisheva AZh, Kiknadze II. 1996. New banding sequences in the Chironomus balatonicus karyofund. Tsitologiya 38(8): 869-883

Gunderina LI, Kiknadze II, Golygina VV. 1999a. Intraspecific differentiation of the cytogenetic structure in natural populations of Chironomus plumosus L., the central species in the group of sibling species (Chironomidae: Diptera). Russian Journal of Genetics 35(2): 142-150.

Gunderina LI, Kiknadze II, Golygina VV. 1999b. Differentiation of the cytogenetic structure of natural populations in the plumosus group of sibling species Chironomus balatonicus, Chironomus entis, Chironomus muratensis, and Chironomus nudiventris (Chironomidae: Diptera). Russian Journal of Genetics 35(5): $506-513$.

Gunderina LI, Kiknadze II, Michailova PV, Krastanov BD. 2008. Variation and divergence of genomic DNA in Chironomus plumosus L. and Chironomus balatonicus Dévai, Wülker, Scholl (Diptera, Chironomidae) of natural populations in Russia and Bulgaria. Eurasian Entomological Journal 7(2): 167-174.

Gunderina LI, Kiknadze II, Istomina AG, Butler MG. 2009. Geographic differentiation of genomic DNA of Chironomus plumosus (Diptera, Chironomidae) in natural Holarctic populations. Russsian Journal of Genetics 45(1): 54-62.

Gunderina LI, Katokhin AV. 2011. Variation and divergence of rDNA ITS-1 region in species of genus Chironomus (Diptera: Chironomidae). In: Xinhua Wang, Wei Liu (eds). Contemporary Chironomid Studies - Proceedings of the XVII Internal Symposium on Chironomidae (6-9 July, 2009 Nankai University, China) Nankai University Press. pp 22-35.

Harrison E, Muir A, Stratford M, Wheals A. 2011. Species-specific PCR primers for the rapid identification of yeasts of the genus Zygosaccharomyces. FEMS Yeast Research 11(4): 356-365.

Kiknadze II, Shiliva AI, Kerkis IE, Shobanov NA, Zelentsov NI, Grebenyuk LP, Istomina AG, Prasolov VA. 1991. Karyotypes and morphology of larvae in tribe Chironomini. Atlas. Novosibirsk. Nauka Publishing. $115 \mathrm{p}$.

Kiknadze II, Butler MG, Golygina VV, Martin J, Wuelker WF, Sublette JE, Sublette MF. 2000. Intercontinental karyotypic differentiation of Chironomus entis Shobanov, a Holarctic member of the C. plumosus group (Diptera, Chironomidae). Genome 43(5): 857-873.

Larkin MA, Blackshields G, Brown NP, Chenna R, McGettigan PA, McWilliam H, Valentin F, Wallace IM, Wilm A, Lopez R, Thompson JD, Gibson TJ, Higgins DG. 2007. ClustalW and
ClustalX version 2 (2007). Bioinformatics 23(21): 2947-2948.

Link W, Dixkens C, Singh M, Schwall M, Melchinger AE. 1995. Genetic diversity in European and Mediterranean faba bean germ plasm revealed by RAPD markers. Theoretical and Applied Genetics 90(1): 27-32.

Michailova P, Fischer J. 1986. Speciation within the plumosus group of the genus Chironomus Meigen (Diptera, Chironomidae). Zeitschrift für zoologische Systematik und Evolutionsforschung 24(3): 207-222.

Moller Pillot HKM. 2009. Chironomidae larvae of the Netherlands and adjacent lowlands. Biology and ecology of the Chironomini. Zeist. The Netherlands. KNNV Publishing. $270 \mathrm{p}$.

Rozen S, Skaletsky HJ. 2000. Primer 3 on the WWW for general users and for biologist programmers. In: Krawetz S, Misener S. (eds). Bioinformatics Methods and Protocols: Methods in Molecular Biology. HumanaPress. Totova. NJ. pp 365-386.

Shobanov NA. 1989. The morphological differentiation of Chironomus species of plumosus group (Diptera, Chironomidae). Larvae. Acta biologica Debrecina. Supplementum oecologica hungarica 2: 335-344.

Stewart LC, Hale RJ, Hale ML. 2010. Species-specific primers for the molecular identification of cryptic Bombus species in New Zealand. Conservation Genetics 11(3):1207-1209. 